\title{
Odchodzenie synonimii z terminologii - na przykładzie polskiej terminologii medycznej przełomu XIX i XX wieku
}

Słow a klucze: leksykografia XIX w.; słowniki XIX w.; polska terminologia medyczna; synonimia

Ke y w ord s: the $19^{\text {th }}$ century lexicography; dictionaries of the $19^{\text {th }}$ century; Polish medical terminology; synonyms

Na przełomie XIX i XX w., na fali intensywnych prac nad polską terminologią medyczną, tzn. jej zbieraniem, porządkowaniem i uzupełnianiem, zostały wydane w Krakowie dwa ważne przekładowe słowniki medyczne: Słownik terminologii lekarskiej polskiej Stanisława Janikowskiego, Józefa Oettingera i Aleksandra Kremera w 1881 r. (dalej: S1881) oraz Stownik lekarski polski Tadeusza Browicza, Stanisława Ciechanowskiego, Stanisława Domańskiego i Leona Kryńskiego w 1905 r. (dalej S1905)ํ․ Ich celem było głównie przygotowanie polskiej terminologii medycznej, która miała obowiązywać po odzyskaniu przez Polskę niepodległości. Leksykony te, redagowane niezwy-

1 Szczegółowy opis kontekstu historycznego, prac nad pol. terminologią med. na tle innych prac nad terminologiami narodowymi tego okresu oraz opis okoliczności powstania i zawartości S1881 i S1905 znajduje się w (Jankowiak 2015c). 
kle starannie i w konsultacji lekarzy krakowskich (autorów S1881 i S1905) z poznańskimi i lwowskimi specjalistami, nie były - co trzeba podkreślić - zapisem stanu polskiej terminologii medycznej w tym okresie, ale przede wszystkim propozycją, jak powinna wyglądać polska terminologia medyczna w przyszłości. Terminologia z S1881 i S1905 stanowi więc przykład niejako „terminologii idealnej”, bo tworzonej świadomie, tzn. również z przekonaniem, że np. synonimia jest zjawiskiem niekorzystnym i trzeba ją eliminować.

Oba leksykony zredagowano na tych samych zasadach, tzn. składają się z 2 części: obcojęzyczno-polskiej i polsko-obcojęzycznej². Oznacza to, że w pierwszej części hasła (ułożone alfabetycznie) pochodzą z różnych języków, głównie z łaciny, ale także - niemieckiego, francuskiego i angielskiego.

Bardzo ważne jest, że w obu słownikach materiał polski przy hasłach obcojęzycznych uporządkowany jest według zasady od najlepszego terminu (nazywam go za (Jankowiak 2015a, b) idealnym terminem) do najmniej polecanego przez autorów słowników.

Przedmiotem analizy w niniejszym artykule jest materiał - szeregi synonimiczne z polskimi nazwami chorób - zebrany z cz. 1. S1881 i S1905. Z 940 takich szeregów synonimicznych (dalej: SZ) z S1881, w S1905 nie zostało odnotowanych 35 . W leksykonie tym zachowały się $703 \mathrm{SZ}$ polskich terminów. Przy hasłach obcych nie zarejestrowano w S1905 polskich SZ, a tylko jeden polski odpowiednik, w 202 przypadkach. I właśnie ta grupa 202 przykładów będzie podstawą omówienia, ponieważ pozwoli ocenić skalę i sposoby eliminacji synonimii w polskiej terminologii medycznej na przełomie XIX i XX w.

Tabela 1. Obecność szeregów synonimicznych z S 1881 w S 1905

\begin{tabular}{|c|c|c|c|}
\hline $\begin{array}{c}\text { Brak hasel obcoję- } \\
\text { zycznych w S 1905 }\end{array}$ & Brak SZ w S 1905 & $\begin{array}{c}\text { Zachowany SZ } \\
\text { w S 1905 }\end{array}$ & Razem \\
\hline 35 & 202 & 703 & $\mathbf{9 4 0}$ \\
\hline $3,7 \%$ & $21,5 \%$ & $74,8 \%$ & $100 \%$ \\
\hline
\end{tabular}

Źródło: opracowanie własne

2 S1881: cz. 1. gromadzi ok. 20 tys. haseł obcojęzycznych z pol. odpowiednikami; cz. 2. - ok. 9 tys. pol. haseł z różnymi (pojedynczymi) odpowiednikami obcymi; S1905: cz. 1. - ok. 36 tys. haseł obcych z pol. odpowiednikami; cz. 2: 12 tys. pol. haseł z odpowiednikami obcymi. 
Wspomniane 202 SZ z S1881, głównie dwuelementowe ${ }^{3}$, rzadziej trójelementowe, nie stanowią jednolitej grupy. Można w ich obrębie wydzielić 3 zespoły przykładów. Kryterium podziału to przede wszystkim polski termin w S1905 i jego stosunek do tzw. idealnego terminu z S1881.

Tabela 2. Podział 202 przykładów

\begin{tabular}{|c|l|l|l|}
\hline I & II & III & razem \\
\hline 82 & 45 & 75 & $\mathbf{2 0 2}$ \\
\hline $40,6 \%$ & $22,3 \%$ & $37,1 \%$ & $100 \%$ \\
\hline
\end{tabular}

Źródło: opracowanie własne

Pierwszy zespół liczy 82 przykłady. W S1905 przy obcojęzycznym haśle jest tylko idealny termin z S1881. Dotyczy to zarówno SZ w S1881 dwuelementowych (np. S1881 rana otwarta, rana jawna - S1905 rana otwarta), jak i liczniejszych, w których automatycznie skala usuwania synonimii jest większa (np. S1881 krwotok mózgowy, wylew krwi na mózg, wylew krwi w mózgu, wybroczenie krwi na mózg, wybroczenie krwi w mózgu - S1905 krwotok mózgowy).

Obecność kwalifikatorów ${ }^{4}$ :

- frekwencyjno-normatywnych

\author{
S188 \\ glejak, [wsporniak] \\ miednica garbatych, [miednica garbata] \\ obłąd opętańczy, [czartobłąd]
}

\section{S1905}

glejak

miednica garbatych

obłęd opętańczy

3 Ten typ SZ jest najliczniejszy wśród 940 SZ z S1881.

${ }^{4}$ Kwalifikatory w S1881 i S1905 wyłącznie informują o pochodzeniu danego terminu, a nie o jego statusie w terminologii ściśle naukowej. Typy kwalifikatorów: a) dziedzinowe, np. okul., pat., chir.; b) chronologiczne: * (nowy wyraz), $\dagger$ (wyraz przestarzały lub wyszły z użycia), dawniej; c) frekwencyjno-normatywne, np. [] (wyraz rzadziej używany lub mniej właściwy), niewłaściwie; d) stylistyczne: posp., pospolicie wadę tę zowią; d) geograficzne, np. warsz. 
- chronologicznych

S1881

gorączka trawiąca, *gorączka suchotna stwardnienie kości, *przetwardnienie kości praw. okaleczenie, $\uparrow$ ochromienie

- geograficznego

S1881

obłąd popędowy, warsz. obłąd instynktowy
S1905

gorączka trawiąca stwardnienie kości praw. okaleczenie

S1905

obłęd popędowy

w $82 \mathrm{SZ} \mathrm{z} \mathrm{S1881,} \mathrm{chociaż} \mathrm{nie} \mathrm{jest} \mathrm{znaczna,} \mathrm{to} \mathrm{mogła} \mathrm{być} \mathrm{dodatkową} \mathrm{przyczy-}$ ną niepojawienia się w S1905 danego terminu.

Porównanie pochodzenia idealnego terminu z S1881 z synonimem, którego nie zarejestrował S1905 pokazuje, że nie miało ono wpływu na odpadnięcie tego terminu na początku XX w. W analizowanym zespole terminy te są wyłącznie rodzime.

Z kolei zestawienie budowy idealnego terminu z S1881 i jego synonimu nieodnotowanego w S1905 pokazuje, że również struktura tych synonimów nie miała większego wpływu na wyeliminowanie drugiego terminu z SZ. Najczęściej bowiem idealny termin z S1881 ma tę samą budowę co synonim, którego nie ma w S1905:

S $1881^{5}$

obłąd popędowy, warsz. obłąd instynktowy pęcherzyca, [niewtaściwie: $\dagger$ bąblica] ropa, [† otok]

\section{S1905}

obłęd popędowy pęcherzyca

ropa

W pozostałych przypadkach, gdy synonim opatrzony kwalifikatorem w SZ z S1881 nie pojawia się w S1905, idealny termin jest nazwą składającą się z większej liczby składników niż termin, którego nie ma w S1905:

${ }^{5}$ Dwa ostatnie przykłady pokazują, że przy terminie nieobecnym w S1905, w S1881 mogło znaleźć się więcej typów kwalifikatorów. 
S1881

obłąd opętańczy, [czartobłąd]

gorączka jednodniowa, *dniówka

niemożność rodzenia mechaniczna, *nierodność
S1905

obłęd opętańczy

gorączka jednodniowa

niemożność rodzenia

mechaniczna

W SZ, w których żaden z terminów nie został opatrzony kwalifikatorem również przeważają przykłady, w których budowa idealnego terminu jest identyczna (najczęściej jednowyrazowa i dwuwyrazowa) z pozostałymi terminami w SZ (32), np.

S1881

miesiączka zbaczająca, miesiączka zdrożna obłąkanie samoistne, obłąkanie idyjopatyczne zakrzep urazowy, zakrzep przyranny

\section{S1905}

miesiączka zbaczająca obłąkanie samoistne zakrzep urazowy

Nieco mniej jest przykładów (24), w których budowa idealnego termi$n u$ z S1881 jest inna niż pozostałych terminów w SZ. Najczęściej (20) wtedy idealny termin ma więcej składników niż jego synonim nieobecny w S1905:

\section{S1881}

nieżyt pęcherzykowy spojówki, nieżyt mieszkowy

plamka na rogówce, rogówka

zapalenie całkowite wielu stawów, zapalenie wielostawowe całkowite

\section{S1905}

nieżyt pęcherzykowy spojówki plamka na rogówce

zapalenie całkowite wielu stawów

Jak pokazują wymienione przykłady, najczęściej odpadający termin jest krótszy o (1 składnik) od idealnego terminu. Na tym tle wyjątkowy jest poniższy przykład, gdy różnica w budowie terminów w SZ jest większa: S1881 zapalenie błony śluzowej macicy, zapalenie wewnatrzmaciczne - S1905 zapalenie błony śluzowej macicy.

Rzadziej zdarza się, że idealny termin ma mniej składników niż nazwa, która nie jest zarejestrowana w S1905 (4), np.

S1881

podnieta kaszlu, bodziec do kaszlu strup, pokrywa zgorzelana

tętno wzrastające, tętno wzmagające się

\section{S1905}

podnieta kaszlu

strup

tętno wzrastające 
Między nieobecnym w S1905 synonimem a idealnym terminem z S1881 zachodzą różne relacje. Po pierwsze, terminy w SZ są względem siebie różnordzenne (13), np.

S1881

garbiak, groniak

zapalenie, zaognienie

złamanie podłużne, pęknięcie
S1905

garbiak

zapalenie

złamanie podłużne

Częściej jednak terminy w SZ są względem siebie wspólnordzenne (np. S1881 stwardnienie kości, *przetwardnienie kości - S1905 stwardnienie kości), a idealny termin i termin odpadający w S1905 najczęściej są synonimami słowotwórczymi, np.

S1881

łożysko przyrosłe, łożysko przyrośnięte

przepuklina uwięzła, przepuklina uwięziona

rozszerzenie serca, rozstrzeń serca
S1905

łożysko przyrosłe

przepuklina uwięzła

rozszerzenie serca

Należą do tych przykładów i takie, gdy termin nieodnotowany w S1905 jest krótszy i utworzony został na drodze kompresji słowotwórczej (np. Górnicz 1997; Musiołek-Choiński 1986: 156-158). Najczęściej powstał przez skrócenie dwuelementowego idealnego terminu, złożonego z rzeczownika i przymiotnika, np. S1881 brodawka morwowata, morówka - S1905 brodawka morwowata. Rzadziej został utworzony z dłuższego niż dwuelementowy idealny termin, np. S1881 niemożność rodzenia mechaniczna, *nierodność - S1905 niemożność rodzenia mechaniczna. Czasem takiemu typowi kompresji może ulec jedynie część składników terminów wieloelementowych, np. S1881 niedostatek tluszczu skórnego, *niedottuszcz skóry - S1905 niedostatek thuszczu skórnego. Innym wynikiem kompresji terminów jest powstanie wyrazu złożonego, np. S1881 cieczenie z ucha, uchotok-S1905 cieczenie z ucha.

Analizując pod innym kątem relacje między idealnym terminem z S1881 i nieobecnym w S1905 terminem, można wskazać na zjawisko, które określam mianem synonimii wtórnej. Pojawia się ono w SZ z terminami wieloelementowymi i związane jest z wchodzącymi w ich skład nazwami: a) anatomicznymi, np. JĄDRO - MUDO (np. S1881 ból jądra, ból mudowy - S1905 ból jądra), PĘCHERZ - MĘCHERZ (np. S1881 przepuklina pęcherzowa, 
przepuklina męcherzowa - S1905 przepuklina pęcherzowa), OPONA - BŁONA (np. S1881 zapalenie opon rdzeniowych, zapalenie błon rdzeniowych - S1905 zapalenie opon rdzeniowych), b) innych chorób, np. HISTERIA MACINNICA (S1881 kula histeryczna, ktębek macinniczy - S1905 kula histeryczna), LISZAJ - OPRYSZCZKA (S1881 liszaj na wargach, opryszczki na wargach - S1905 liszaj na wargach). W tych przypadkach do odchodzenia danego terminu wieloelementowego na początku XX w. może przyczyniać się zawarta w nim inna (krótsza) nazwa (starsza lub rzadziej używana).

Drugi zespół to 45 przykładów (22,3\%), gdy w S1905 zamiast SZ pojawia się polski termin inny niż idealny termin z S1881. Dotyczy to przede wszystkim dwuelementowych SZ z S1881 (35, np. S1881 kamyk moczowy oczepiony, kamyk moczowy otorbiony - S1905 kamyk moczowy otorbiony).

Dodatkowo w tym zespole znajduje się kilka takich przykładów (4), w których w S1905 zarejestrowany jest synonim w S1881 opatrzony jakimś kwalifikatorem. Kwalifikatorem, który - można by przypuszczać - powinien go raczej dyskwalifikować niż nobilitować do rangi najlepszego terminu w S1905:

- chronologicznym

S1881

patol. artrytyzm, $\uparrow \mathrm{dna}$

chir. otwór wchodowy przestrzału, *wlot przestrzału

- frekwencyjno-normatywnym

S1881

choroba nerwowa ruchowa, [nerwica ruchowa] puchlina głowowa, [wodogłowie]
S1905

dna

chir. wlot postrzału

W SZ z S1881, które składały się z 3 terminów (10), w S1905 jedynym jest synonim (czasem z kwalifikatorem) znajdujący się w S1881 na ostatnim miejscu (czyli termin najmniej polecany), np.

S1881

obłąd z szałem, obłąd szałowy, szaleństwo puchlina worczasta, puchlina torbielowa,
S1905

szaleństwo

puchlina otorbiona

puchlina otorbiona 
terat. wstrzymany rozwój, niedokształcenie utwór z powstrzymanego rozwoju, *niedokształcenie

Rzadko jest to środkowy synonim (5), np.

S1881

skrzeplina krwi, skrzeplina, skrzep krwi, stężyna tchnienie, oddech krótki, oddech trudny wykrzywienie, wykręcenie, wybicie
S1905

skrzep krwi oddech krótki wykręcenie

W tym zespole zmiany w synonimii są nie tylko liczbowe (SZ z S1881 zostaje zredukowany do jednego terminu w S1905), lecz także jakościowe (w S1905 przy haśle obcojęzycznym proponuje się inny termin niż w S1881 uznany za najlepszy, czasem nawet najgorszy termin).

Różnice między zachowanym terminem w S1905, a odchodzącym(-ymi) dotyczą też - w niewielkim stopniu - pochodzenia terminów (S1881 patol. artrytyzm, $\uparrow$ dna - S1905 dna) oraz ich budowy. Zarówno w SZ dwuelementowych, jak i trójelementowych termin z S1905 ma budowę:

- (najczęściej) identyczną z idealnym terminem z S1881 (27), np.

\section{S1881}

choroba zjadliwa, choroba złośliwa

obłąd mężobójczy, obłęd morderczy

przegryzienie, przeżarcie
S1905

choroba złośliwa

obłęd morderczy

przeżarcie

- mniej skomplikowaną niż idealny termin z S1881 (8), np.

S1881

mocz białczysty, białkomocz

obłąd z szałem, obłąd szałowy, szaleństwo terat. wstrzymany rozwój, utwór z powstrzymanego rozwoju, *niedokształcenie
S1905

białkomocz

szaleństwo

niedokształcenie

- bardziej skomplikowaną niż idealny termin z S1881 (6), np.

S1881

nadrost, guz paznogciowy
S1905

guz paznokciowy 
strupień śliwiący, strupień ślimaczący

(na głowie)

szmer dżdżowy, szmer padającego deszczu strupień ślimaczący się

(na głowie)

szmer padającego deszczu

Między idealnym terminem z S1881 a jego synonimem, który pozostaje w S1905, zachodzą różne relacje. Terminy mogą być względem siebie różnordzenne (10), np.

S1881

przepacanie, przesiąkanie

pytaczka, obłąd wywiadowczy

zaduch, miazmat
S1905

przesiąkanie

obłęd wywiadowczy

miazmat

Częściej (33) jednak są wspólnordzenne (np. S1881 zapalenie odoskrzelowe, zapalenie okołoskrzelowe - S1905 zapalenie około oskrzelowe), a zwykle są synonimami słowotwórczymi, np.

S1881

gorączka następnicza, gorączka następowa szał durzycowy, szał durowy

widzenie przez połowę, widzenie połowicze
S1905

gorączka następowa szał durowy

widzenie połowicze

Szczególnym przypadkiem jest sytuacja, gdy termin pozostający w S1905 jest krótszy i powstał z idealnego terminu (z S1881) w wyniku kompresji stowotwórczej, np. S1881 zaćma torebki soczewkowej, albo krócej: zaćma torebkowa - S1905 zaćma torebkowa. Kompresji może też ulec jedynie część składników terminów wieloelementowych, np. S1881 choroba nerwowa ruchowa, [nerwica ruchowa] - S1905 nerwica ruchowa. Z kompresji terminów powstał też wyraz złożony z 2 pojedynczych z S1881 mocz białczysty, biatkomocz - S1905 białkomocz.

Wśród synonimów słowotwórczych trzeba zwrócić uwagę na przykłady terminów dwuelementowych, które stanowią swoje odwrócenie, tzn. wyraz, który był podstawą, stał się określeniem i odwrotnie. Opisała to zjawisko w terminologii technicznej J. Nawacka (1978). W zgromadzonym materiale są jedynie podobne (nieliczne) przykłady odwrócenia budowy, w których jednak nie następuje zmiana części mowy w przypadku obu członów zestawienia, lecz tylko jednego, np. S1881 zwatpiałość obtędna, obłąd wątpienia - S1905 obtęd watpienia. 
Również w tym zespole są przykłady synonimii wtórnej w SZ z terminami wieloelementowymi, w których składzie pojawiają nazwy: a) anatomiczne, np. ŻYŁA BRAMNA - ŻYŁA WROTNA (np. S1881 zakrzep żyły bramnej, zakrzep żyly wrotnej - S1905 zakrzep żyty wrotnej), SKORÓWKA - KOSMÓWKA (S1881 zwyrodnienie groniaste skorówki, zwyrodnienie groniaste kosmówki - S1905 zwyrodnienie groniaste kosmówki) oraz b) innych chorób, np. BĄBEL - PĘCHERZ (S1881 bąbel zgorzelinowy, pęcherz zgorzelinowy - S1905 pecherz zgorzelinowy), OBŁĘD - SZAŁ - SZALEŃSTWO (np. S1881 obład z szałem, obłąd szałowy, szaleństwo - S1905 szaleństwo), PĘCHERZYK - PRYSZCZ (S1881 osutki pęcherzykowe, osutki pryszczykowe - S1905 osutki pryszczykowe).

W omawianych 202 przykładach najbardziej skomplikowany jest trzeci zespół przykładów 75 (37,1\%). Przy haśle obcojęzycznym w S1905 pojawia się nowy termin, tzn. nieobecny w SZ z S1881. Zespół ten to najlepszy przykład pozornego odchodzenia synonimii z polskiej terminologii medycznej na przełomie XIX i XX w., np.

S1881

ból udowy położnic, obrzęk udowy położnic gorączka gośćcowa, gorączka reumatyczna zniedołężnienie umysłowe z porażeniem postępowem, warsz. bezwład postępowy

\section{S1905}

bolesny obrzęk uda u położnic gościec stawowy ostry zniedołężnienie umysłowe poraźne

Zmiany zachodzą tu głównie w SZ składających się z 2 terminów w S1881 (62, np. S1881 powietrze zachówkowe, powietrze pozostałe - S1905 powietrze zalegajace), chociaż znalazły się tu też dłuższe SZ: trzy- (7, np. S1881 odpad$k i$, rozpad, rozpadki - S1905 miazga (z rozpadu tkanki)) i czteroelementowe (2, np. S1881 przepuklina thuszczowa koło jąder, przepuklina ttuszczowa koło mad, guz tłuszczowy koło jader, guz tłuszczowy koło mąd - S1905 przepuklina tluszczowa).

Powyższe zmiany dotyczą również SZ z S1881, które miały co najmniej przy jednym synonimie jakiś kwalifikator:

- frekwencyjno-normatywny, np.

S1881

położn. guzy mleczane, [rozstrzeń mleczna] przepuklina sieciowa, [przepuklina kałdunowa]
S1905

torbiel mleczna sutka przepuklina sieciowo-jelitowa 
zapalenie gardła błonicowe,

zapalenie gardła błonicze

[zapalenie gardła dyfteryczne]

- chronologiczny, np.

S1881

* przegłód, † przemor

czop zatorny, zatornik, *zatorek

marskość wątroby, zapalenie śródmiąższowe

rozlane wątroby, $\uparrow$ zziarnienie wątroby
S1905

wilczy głód

pat. czop

marskość

Niewielki wpływ na pojawienie się w S1905 zupełnie nowej nazwy zdaje się mieć zarówno jej pochodzenie, jak i terminów w S1881. Nieliczne są bowiem przykłady, gdy na miejsce rodzimych terminów z S1881 wchodzi w S1905 nazwa pochodzenia obcego: S1881 ślizienica, biegunka pokarmowa - S1905 lienterya; S1881 wrzód w nosie, owrzodzenie wjamie lubjamach nosowych - S1905 ozena.

Również budowa synonimów w S1881 i nowej nazwy w S1905 nie wydaje się istotna, bo w aż 34 przypadkach mają one identyczną budowę, np.

S1881

czucie płciowe przewrotne, popęd płciowy przewrotny

przepuklina pępkokałdunowa, przepuklina pępkosadłowa

zapalenie kolana zjadliwe, zapalenie kolana złośliwe
S1905

czucie płciowe opaczne

przepuklina pępkowosieciowa

gruźlica stawu kolanowego

W pozostałych przykładach termin w S1905 ma budowę

- $\quad$ prostszą niż terminy z S1881 (9), np.

S1881

zimnica trzeciaczka, $†$ zimnica przezdzienna, $\dagger$ zimnica przesednia

zapalenie około kiszki odchodowej, zapalenie około kiszki odbytowej

zapalenie stawu biodrowego zjadliwe, zapalenie stawu biodrowego złośliwe
S1905

trzeciaczka

zapalenie okołoodbytnicze

gruźlica stawu biodrowego 
- bardziej skomplikowaną niż terminy z S1881 (12), np.

S1881

guz krwawnicowy, szyszka krwawnicowa

miednica poprzecznie ścieśniona, miednica

poprzecznie zwężona

przepuklina sieciowa, [przepuklina kałdunowa]
S1905

zawiędły guz krwawniczy

miednica poprzecznie

ścieśniona wskutek zrostu

przepuklina sieciowo-jelitowa

W pozostałych (20) przykładach budowa terminów jest różna, np.

S1881

położn. pochylenie kręgosłupa w miednicy,

*kręgochył

zapalenie błonicowe jamy ust, zapalenie

dyfteryczne jamy ust, błoniawa gęby

zniedołężnienie umysłowe z porażeniem

postępowem, warsz. bezwład postępowy

\section{S1905}

osiadanie się kręgosłupa

błonica jamy ustnej

zniedołężnienie umysłowe

poraźne

Terminy w S1881 i nowy termin w S1905 pod tym samym hasłem obcojęzycznym mogą być względem siebie różnordzenne, np.

\section{S1881}

starcie, przetarcie

ślizienica, biegunka pokarmowa

włosozrost niszczący, włosozrost golący

\section{S1905}

ubytek

lienterya

grzybek strzygący

Częściej jednak nowa nazwa jest przynajmniej z jednym $\mathrm{z}$ terminów z S1881 wspólnordzenna (np. S1881 ognisko rozpadu, ognisko nekrotyczne - S1905 ognisko rozpadowe), a najczęściej jest synonimem słowotwórczym jednego z terminów w S1881 (12), np.

S1881

krwistość trzewna, krwistość trzewowa,

krwistość brzuchowa

opadnienie pęcherza moczowego, opad męcherza

zapalenie gardła błonicowe, [zapalenie gardła

dyfteryczne]
S1905

krwistość brzuszna

opadnięcie pęcherza moczowego

zapalenie gardła błonicze 
Ponadto, termin zaproponowany w S1905 może stanowić połączenie:

- synonimów z SZ w S1881 (4), np.

S1881

choroba zakaźna, choroba ostra

ropa gęsta, ropa krwawa

śluzotok oskrzelowy, ropotok oskrzelowy

- części składowych synonimów z S1881 (2):

\section{S1881}

epilepsya histeryczna, padaczka macinnicza

glejak siatkowato-komórkowy,

[wsporniak pająkowaty]

\section{S1905}

choroba zakaźna ostra

ropa gęsta krwawa

śluzoropotok oskrzelowy

Czasem nowa nazwa z S1905 stanowi skrót terminów z S1881 (6), bo powstaje w wyniku kompresji synonimu: jednego (4, np. S1881 torbiak jajnikowy złożony, (torbiel jajnikowy złożony) - S1905 torbiak jajnikowy), kilku (S1881 przepuklina tluszczowa koło jader, przepuklina thuszczowa koło mąd, guz tłuszczowy koło jąder, guz tłuszczowy koło mąd-S1905 przepuklina tłuszczowa) lub wszystkich z SZ (S1881 gościec stawowy nagły, gościec stawowy ostry - S1905 gościec stawowy).

Niekiedy nowy termin z S1905 stanowi rozszerzenie jednego z synonimów z S1881 (3):

S1881

drżączka, trzęsawka

miednica poprzecznie ścieśniona, miednica poprzecznie zwężona

*naskórniak, pasożyt naskórny
S1905

drżączka poraźna

miednica poprzecznie

ścieśniona wskutek zrostu pasożyt naskórny zwierzęcy

Również w tym zespole są przykłady nazw, które stanowią swoje odwrócenie, np. S1881 skorupa brudu z tupieżem u noworodków na ciemiączu, ciemiączko złupieżone - S1905 patol. złupieżenie ciemiączka.

Zjawisko synonimii wtórnej obecne jest także w tym zespole przykładów i w składzie terminów wieloelementowych pojawiają się nazwy: a) anatomiczne, np. MĘCHERZ - PĘCHERZ MOCZOWY (np. S1881 zapalenie omęcherzowe, zapalenie okołomęcherzowe - S1905 zapalenie okołopęcherzowe), JĄDRO - MUDO - MOSZNA (S1881 przepuklina jądrowa, przepu- 
klina mudowa-S1905 przepuklina mosznowa), GRUCZOŁ TARCZYKOWY - GRUCZOŁ TARCZOWATY - GRUCZOŁU TARCZOWY (S1881 zapalenie gruczołu tarczykowego, zapalenie gruczołu tarczowatego - S1905 zapalenie gruczołu tarczowego) oraz b) innych stanów chorobowych, np. GUZ - TORBIEL (S1881 położn. guzy mleczane, [rozstrzeń mleczna] - S1905 torbiel mleczna sutka), PORONIENIE - RONIENIE (S1881 poronienie z usposobienia, poronienie przywykte - S1905 ronienie nawykowe), TRZE_SIENIE - DRESZCZ (S1881 trzęsienie mroźne, dreszcz mocniejszy - S1905 dreszcz (wstrzasajacy)), WRZÓD - WYPRYSK (S1881 wrzód moczowy, wrzód liszajowy - S1905 wyprysk saczacy).

Okres między wydaniem krakowskich słowników, S1881 i S1905, przygotowywanych przez różnych autorów, jest wystarczający, by wskazać pierwsze zmiany w synonimii polskiej terminologii medycznej ${ }^{6}$. Jednak interpretując liczbę i charakter tych zmian, trzeba pamiętać, że dotyczą terminologii zawartej w słownikach, które tylko częściowo odzwierciedlały jej stan faktyczny na przełomie XIX i XX w. i przede wszystkim były propozycją, jak powinna wyglądać polska terminologia medyczna w przyszłości.

Okazuje się, że kolejne prace (do 1905 r.) nad polską terminologią lekarską (niejako, ,idealną terminologią”), chociaż prowadzone były niemal w warunkach „laboratoryjnych” i m.in. ze świadomością, że synonimia jest zjawiskiem niekorzystnym, nie doprowadziły do jej całkowitego wyeliminowania. Na 940 SZ z S1881 w ciągu 24 lat zaledwie 202 SZ nie pojawiły się w S1905, czyli synonimia nie tylko jest w tym czasie ciągle obecna, lecz także odznacza się znaczną trwałością - w ponad 74\% (por. Jankowiak 2018a).

Z kolei w omówionych 202 przykładach (tj. ponad 21\%), gdzie zmiany w zakresie synonimii zaszły, nie można jednoznacznie stwierdzić, że - ponad wszelką wątpliwość - eliminacja synonimii nastąpiła. W 75 przypadkach (zespół III) doszło bowiem tylko do pozornego jej likwidowania (ok. 8\%) na przełomie XIX i XX w. Chociaż w przypadku tego zespołu w S1905 nie ma już SZ, to jednak termin zaproponowany w S1905 nie był wcześniej zareje-

${ }^{6}$ Pokazały to również inne badania. Por. np. (Jankowiak 2018a, b). 
strowany w SZ z S1881. Tak więc jest to raczej przykład zwiększania skali synonimii w tym okresie niż jej pomniejszania.

Inaczej można ocenić dopiero zmiany w pozostałych 2 zespołach. Pierwszy z nich $(82 ; 8,7 \%)$ to niewątpliwie przykład pełnej eliminacji synonimii. W S1905 nie ma SZ, a jedynym terminem zaproponowanym pod hasłem obcojęzycznym jest idealny termin z S1881. Wybór w S1905 najbardziej polecanego synonimu z S1881 świadczy o znacznym wyczuciu językowym autorów słownika z 2. poł. XIX w., którzy - mimo pewnego wahania przy tworzeniu tego leksykonu, dowodem którego to wahania jest zaproponowanie SZ polskich terminów przy haśle obcojęzycznym, a nie jednego terminu - wskazali od razu termin, który został uznany za najlepszy w następnym stuleciu. Z kolei w zespole 45 przykładów usuwaniu synonimii towarzyszy wybór terminu w S1905, który był w S1881 na innym niż pierwsze miejsce w SZ (nawet mógł to być najmniej polecany tam termin). Chociaż ten typ zmian trzeba ocenić niżej, to jednak niewątpliwie synonimia zostaje tu wyeliminowana. Łącznie więc w tych 2 zespołach (127) synonimia odchodzi na poziomie 13,5\%. Jak widać z powyższego, analizując i oceniając skalę eliminacji synonimii, trzeba brać pod uwagę zarówno zmiany ilościowe, jak i jakościowe.

Redukcja synonimii dotyczyła SZ, które w S1881 były przede wszystkim dwuelementowe, w mniejszym stopniu - trójelementowe SZ (obie grupy SZ są najliczniejsze wśród 940 przykładów wyjściowych), niezwykle rzadko w SZ liczniejszych. W tych ostatnich skala eliminacji synonimii jest większa, odpadło bowiem więcej terminów.

Niezależnie od tego jednak, czy synonimia została zlikwidowana faktycznie (13,5\%) czy pozornie (8\%), trudno znaleźć przyczyny językowe tych zmian. Zarówno o wyeliminowaniu synonimu z SZ (z S1881), jak i - w S1905 - pozostawieniu terminu z S1881 lub wprowadzeniu nowej nazwy (jak w zespole III - 75 przykładów), nie zadecydowało ani pochodzenie terminów, ponieważ udział wyrazów zapożyczonych w analizowanym materiale jest nikły, ani udział kwalifikatorów przy synonimach terminologicznych, które odpadły w S1905, albo w tym słowniku zostały zarejestrowane.

Również budowa samego SZ w S1881 oraz synonimów wchodzących w jego skład nie miały wpływu na zmiany w synonimii, bowiem nie jest rzadkością, że termin w S1905 ma identyczną budowę z idealnym terminem z S1881, rzadziej - bardziej skomplikowaną (czyli mniej ekonomiczną). Ponadto terminy obecne pod tymi samymi hasłami obcojęzycznymi w obu 
leksykonach najczęściej są wobec siebie wspólnordzenne, a nawet przynajmniej jeden termin z SZ z S1881 jest synonimem słowotwórczym terminu odnotowanego w S1905. Oznacza to, że zmiany w synonimii w polskiej terminologii medycznej przełomu XIX i XX w. są częściej wyrazem ogólnej tendencji w polszczyźnie tego okresu, tzn. znacznej obecności synonimii słowotwórczej (np. Buttler 1972, 1975, 1984), niż przemian tylko w zakresie terminologii. Motywacja przemian w synonimii jest więc inna niż tylko terminologiczna.

Inny typ zmian wynika z obecności (na dużo mniejszą skalę) zjawiska synonimii wtórnej. Zmiany w synonimii nazw chorób są efektem przekształceń w zakresie synonimii innych działów medycyny, np. anatomii.

Podsumowując uwagi na temat skali odchodzenia synonimii z polskiej terminologii medycznej przełomu XIX i XX w., biorąc pod uwagę rozpatrywany czas wystąpienia zmian w tym zakresie, należy ocenić, że eliminacja synonimii (faktyczna czy pozorna) w ponad $20 \%$ jest ważna i warta odnotowania. Czy jest znaczna? To można będzie rzetelnie ocenić tylko na tle badań porównawczych synonimii i jej przemian w innych okresach w rozwoju polskiej terminologii lekarskiej. Niestety dotychczasowe opracowania dotyczą, oprócz 2. połowy XIX w. (Jankowiak 2015c), jedynie opisu stanu synonimii w XVI w. (Jankowiak 2005: 70-88).

\section{Bibliografia}

Browicz T., Ciechanowski S., Domański S., KryŃski L., 1905, Słownik lekarski polski [S1905], Kraków: Towarzystwo Lekarskie Krakowskie, Drukarnia Uniwersytetu Jagiellońskiego.

Buttler D., 1972, Zmiany słownikowe w polszczyźnie przełomu w. XIX i XX, Poradnik Językowy, z. 4, s. 196-204.

ButTler D., 1975, Rozwój słownictwa polskiego w drugiej połowie XIX wieku, w: Slovanské spisovné jazyky v době obrození, Praha: Univerzita Karlova, s. 97-102.

Buttler D.,1984, Zmienność znaczeń wyrazów w polszczyźnie przełomu XIX i XX wieku, cz. 3, Poradnik Językowy, z. 5, s. 277-289.

Górnicz M., 1997, Sposoby i granice kompresji terminów (Na podstawie terminologii medycznej - nazwy nowotworów), Poradnik Językowy, z. 2, s. 25-32.

Janikowski S., OetTinger J. Kremer A., 1881, Stownik terminologii lekarskiej polskiej [S1881], Kraków: Towarzystwo Lekarskie Krakowskie. 
Jankowiak L. A., 2005, Słownictwo medyczne Stefana Falimirza. T. 1: Poczatki polskiej renesansowej terminologii medycznej, Warszawa 2005: SOW.

JANKOWIAK L. A., 2015a, Budowa synonimów głównych w polskiej terminologii medycznej drugiej połowy XIX wieku, Studia Językoznawcze. Synchroniczne i diachroniczne aspekty badań polszczyzny 14, s. 367-390, [on-line:] DOI: 10.18276/ sj.2015.14-23

JANKOWIAK L. A., 2015b, Koncepcja idealnego terminu w świetle Słownika terminologii lekarskiej polskiej z 1881 r., Poznańskie Studia Polonistyczne. Seria Językoznawcza 22(42), z. 1, s. 81-89, [on-line:] DOI: 10.14746/pspsj.2015.22.1.5

Jankowiak L. A., 2015c, Synonimia $w$ polskiej terminologii medycznej drugiej połowy XIX wieku (na podstawie Słownika terminologii lekarskiej polskiej z 1881 roku), Warszawa: SOW.

JANKOWIAK L. A., 2018a, Trwałość synonimii $w$ polskiej terminologii medycznej przełomu XIX $i$ XX wieku, [w druku].

JANKOWIAK L. A., 2018b, Trwałość idealnego terminu na przykładzie polskiej terminologii medycznej przełomu XIX i XX wieku, [w druku].

Musiolek-Choiński K., 1986, Polskie nazwy chorób. Studium z terminologii medycznej, Wrocław: Wydawnictwo Uniwersytetu Wrocławskiego.

NAwACKA J., 1978, O synonimach typu fundament ławowy \| ława fundamentowa, Poradnik Językowy, z. 4, s. 160-164.

\section{Withdrawal of synonymy from terminology as exemplified by the Polish medical terminology at the turn of the 19th and 20th century \\ ( s u m m a r y )}

An examination of the lexical material contained in Stownik terminologii lekarskiej polskiej [Polish Medical Terminology Dictionary] of 1881 and Stownik lekarski polski [Polish Medical Dictionary] of 1905 shows that the synonymy withdrawal rate in this period was only $20 \%$. The purpose of the article is to provide a detailed description of this process, including the process of an apparent withdrawal of synonymy in the lexicon of 1905 (e.g. some foreign language entries have not been recorded there at all; sometimes a synonymic string was removed while leaving a new term next to the foreign language entry, "new" meaning absent in the dictionary of 1881). 
